\title{
Teologia e Literatura: espiritualidade, poesia e memória
}

\section{Theology and Literature: spirituality, poetry and memory}

\author{
Erik Dorff Schmitz* \\ UFSC \\ Fernando Steffens**
}

Recebido em: 08/04/2021. Aprovado em: 22/04/2021.

Resumo: Nesse artigo iremos acenar como Literatura e Teologia se relacionam num tripé: espiritualidade, poesia e memória. Traremos as criações de alguns poetas e poetisas que em suas obras manifestam uma espiritualidade mística que provocam um correlacionamento entre a arte literária e a reflexão teológica. Buscaremos algumas obras de Carlos Drummond de Andrade, Adélia Prado, Mario Quintana, Ferreira Gullar, Fernando Pessoa, José Tolentino de Mendonça, Manuel de Barros, Murilo Mendes, Nicanor Parra e a partir delas usaremos o suporte da Teopoética, que consiste em uma reflexão acadêmica entre Literatura e Teologia, trazendo estudos já realizados por teóricos da área. Com isso queremos mostrar como é possível fazer poesia com espiritualidade, e como a Teologia pode fazer bom proveito da arte poética para a fé.

Palavras-chave: Teologia. Literatura. Espiritualidade. Poesia. Memória.

Abstract: In this article we will present Literature and Theology if we relate in travel: spirituality, poetry and memory. We will bring as creations of some poets

* Doutorando em Literatura (Universidade Federal de Santa Catarina - UFSC, Florianópolis, SC). Mestre em Literatura (Universidade Federal de Santa Catarina - UFSC, Florianópolis, SC, 2019). Bacharel em Teologia (Faculdade Católica de Santa Catarina - FACASC, Florianópolis, SC, 2015). Bacharel em Filosofia (Faculdade São Luiz FSL, Brusque, SC, 2011). Graduando em Letras Português (Universidade Federal de Santa Catarina, UFSC, Florianópolis, SC).

E-mail: erik.schmitz@hotmail.com

** Pós-Graduando em Juventude, Religião e Cidadania (Faculdade Católica de Santa Catarina-FACASC, Florianópolis, SC). Bacharel em Teologia pela Faculdade Católica de Santa Catarina - FACASC, Florianópolis, SC, 2015). Bacharel em Filosofia pela Faculdade São Luiz - FSL, Brusque, SC, 2010).

E-mail: fernando.ssteffens@gmail.com 
and poets who in their works manifest a mystical spirituality that causes a correlation between literary art and theological reflection. Research some works by Carlos Drummond de Andrade, Adélia Prado, Mario Quintana, Ferreira Gullar, Fernando Pessoa, José Tolentino de Mendonça, Manuel de Barros, Murilo Mendes, Nicanor Parra and from how to use the support of Teopoética, which is a strategy between Literature and Theology, brings studies already carried out by theorists in the field. With this we want to show how it is possible to make poetry with spirituality, and how theology can make good use of poetic art for the faith.

Keywords: Theology. Literature. Spirituality. Poetry. Memory.

"E eis que, tendo descansado no sétimo dia, os poetas continuaram a obra da Criação."

(Mário Quintana) $)^{1}$

\section{Introdução}

Iniciamos com o Versículo inédito do Gênesis que, de imediato, conduz-nos a uma verdade teológica e, ao mesmo tempo, leve, delicada e elegantemente une a poesia e a fé, a teologia e a arte, pois, impossível não pensar na Sagrada Escritura, no início de tudo, no mistério das primeiras tardes ao lermos esse verso. A habilidade do poeta já indica o significado do que vem a ser a poesia: do grego poiesis, arte de criar, ação de fazer algo. Ou seja, continuar a obra.

O tema desse artigo é Literatura e Teologia, onde iremos investigar como espiritualidade, poesia e memória se relacionam entre si, sem que seja necessário obedecer a uma hierarquia entre elas. Ambas nascem juntas e convivem juntas, feito fogo e calor. A Literatura muitas vezes é espiritual, mística, transcendente, orante. Por outro lado, a Teologia se perfuma de poesia, de uma linguagem que ultrapassa o dogmático, o lógico, o irrefutável, sem jamais abandonar a verdade - que isto fique claro. Fé e poesia em perfeita simetria com a Verdade.

\section{Teologia e Literatura}

Atualmente há no ambiente acadêmico a consolidação dos diálogos entre Teologia e Literatura - a Teopoética - que vem unir essas duas áreas de forma investigativa. Um dos primeiros que buscou sistematizar

1 QUINTANA, Mario. Mario Quintana: poesia completa: em um volume. Org. Tania Franco Carvalhal. Rio de Janeiro: Nova Aguilar, 2005. p. 239. 
a relação entre essas duas áreas do conhecimento, foi o alemão Karl Josef Kuschel, autor de Os escritores e as escrituras: retratos teológicos literários. Em seu livro, ele expõe que:

Se o século XIX já tentara restabelecer a união entre teologia e literatura - o primeiro apelo por uma literatura cristã, do ponto de vista da história literária, ocorre no movimento romântico (inicialmente com Schlegel, em sua face tardia, e depois com Einchendorf, Brentano e Anette von Droste-Hülshoff) -, isto já se revela como sintoma precoce do distanciamento entre cultura e religião. [...] Houve reações adversas de ambas as partes, e é com isso que este livro pretende se ocupar já de início: com a crítica estético-literária à religião, mas também com a crítica religiosa à estética. ${ }^{2}$

A Teopoética busca desde o primeiro passo dado pelos românticos na arte, essa crítica estético-literária à religião, e também uma crítica religiosa à estética, à arte. Mas só no século XX a Teologia e a Literatura começam a aprofundar sua relação em alguns círculos acadêmicos, possibilitada pelos avanços nos estudos bíblicos com base no método histórico crítico e nas revoluções culturais do século passado. Após a estética romântica buscar ligar os pontos entre o sagrado e o profano, a Teologia e a Literatura começam a se dar as mãos.

Nessa busca pela verdade, o catedrático escreve uma densa tese, publica ensaios, vasculha bibliotecas em busca de argumentos e os agrupa num longo texto, comumente chato e cansativo. Não contente, lê mais livros, rascunha novos teorias e vai acrescentando notas bibliográficas às convicções defendidas. $\mathrm{O}$ poeta escreve um verso, e nele encontra um silêncio que fala, cala, responde, preenche e anula a necessidade dos argumentos. Pensando, por exemplo, nos processos de amadurecimento do ser humano, a Psicologia constrói os mais diferentes mapas do funcionamento da mente, a Teologia elabora doutrinas sólidas que definem os modos da atuação da graça em nós, a Filosofia elabora questões e tenta respondê-las a partir das mais diversas perspectivas, sempre numa tentativa de dizer que as fases da vida ocasionam transformações profundas, cujas consequências inevitavelmente irão surgir e que todos estamos sujeitos a mudanças, a traumas, às circunstâncias, assim por diante. $\mathrm{O}$ poeta simplesmente diz: "Quando dês opinião, nunca deixes de escrever

2 KUSCHEL, Karl Joseph. Os escritores e as escrituras: retratos teológicos-literários. São Paulo: Loyola. 1999. p. 13-14. 
a data..." (Mario Quintana) ${ }^{3}$. Com humor e profundidade, poesia e leveza, verdade e sem rodeios, todo o movimento da vida foi descrito. Com isso apenas queremos dizer que na poesia a verdade é mais facilmente traduzida, particularmente aquelas que misturam o humano e o divino.

O momento atual em que se encontram as reflexões entre Teologia e Literatura redescobre para dentro da reflexão teológica o direito de cidadania da espiritualidade cristã, que permite à teologia de hoje dizer novas palavras. Deixando um pouco de lado velhas retóricas proselitistas, apologéticas e moralistas, a Teologia tem hoje a alegre oportunidade de retirar algumas de suas cascas enrijecidas pelo excesso de doxa, e olhar um pouco além dos muros das instituições. Para isso é necessária uma afinidade, um dobrar-se, tanto da Teologia como da Literatura, e ambas encontrarem o que as une, deixando de lado o que as divide, ou dividia. Maria Clara Bingemer aponta dois elementos constitutivos tanto do fazer teológico como da criação literária: a inspiração e a palavra:

$A$ inspiração: na origem tanto da literatura quanto da teologia está o fenômeno da inspiração. A respeito da inspiração, a fisiologia e a Bíblia nos dizem que tem a ver com o ar em nossos pulmões. Esse ar, sem o qual não se vive, diz a Bíblia que é como o próprio Espírito de Deus, que leva e traz a vida, sem se saber de onde vem nem para onde vai $(J o 3,1) .{ }^{4}$

Para a Teologia, foi sob a força da inspiração que os profetas disseram com boca humana as palavras divinas e os hagiógrafos escreveram os textos posteriormente compilados no cânon bíblico:

A palavra: quando dizemos que o meio de expressão literário é a palavra, ultrapassamos o significado etimológico de literatura, que deriva do latim littera-letra-, e parece referir-se, portanto, de modo primordial, à palavra escrita ou impressa. Contudo, muitas civilizações, desde a grega antiga até a escandinava, a francesa e a inglesa, produziram importantes tradições orais. Inclusive, extensos poemas narrativos - como a Ilíada $e$ a Odisseia, de Homero, as sagas islandesas e o Beowulf anglo-saxônico - foram, presumivelmente, cantados ou entoados por rapsodos e bardos profissionais, séculos antes de terem sido passados a escrito. ${ }^{5}$

3 QUINTANA, 2005, p. 366.

4 BINGEMER, Maria Clara. Teologia e Literatura: afinidade e segredos compartilhados. Petrópolis: Vozes, 2015. p. 16.

5 BINGEMER, 2015, p. 16-17. 
Dessa forma a Teologia e a Literatura também tem sua origem na palavra. Para a Teologia, essa palavra se crê pronunciada por Deus e pelo ser humano na história. A Literatura é considerada uma arte verbal, primeiramente oral, depois escrita, impressa e divulgada também na história da humanidade.

\section{O universo místico da poesia}

Na Bíblia, encontramos diversos gêneros literários que compõe seus textos: mitos, sagas, legislações, poesias, cantos, relatos históricos, biografias, cartas, etc. Dentre estes, o poético se destaca. O mais extenso livro da Bíblia, o dos Salmos, é todo feito de poesia. No salmo 44 (45), o salmista inicia dizendo: "Transborda um poema do meu coração". E se navegarmos por esse imenso oceano textual, a poesia estará presente na boca dos profetas, dos sacerdotes, dos reis, de Jesus, das mulheres, nas referências à natureza - aqui de um modo todo especial: "Os rios levantam sua voz"; "Batam palmas os rios, e as montanhas juntas rejubilem de alegria" (S1 93 e 98); "Lua e sol, bendizei ao Senhor" (Dn 3,62) -, também em São Paulo que faz referência aos poetas gregos, quando do seu discurso no Areópago, em Atenas: "Porque é nele que temos a vida, o movimento e o ser, como até alguns dos vossos poetas disseram: Nós somos também de sua raça..." (At 17,28) e cita um verso do poeta Menandro: "As más companhias corrompem os bons costumes." (1Cor $15,33)$ Isso apenas para fazer um tímido aceno à presença poética no texto sagrado.

O texto sagrado, escrito por mãos humanas, representa as mais variadas sensações, desejos, devaneios, inquietações da pessoa humana que busca no transcendente um alento para as situações limites da vida cotidiana. É uma comunicação humana, a despeito de algo divino, ou divinizado, dentro do coração humano, com afirma Eli Brandão:

Quanto a sua configuração, seja qual for o texto, mesmo o que conta de algo de um universo sagrado, não deixa de ser um texto comum, um meio de comunicação entre homens, no qual um autor busca deixar suas impressões em um código destinável a ser decifrável por outros seres humanos, não havendo referência extra-humana nem do lado do emissor, nem do receptor, sem que o texto deixe de ser comunicação humana, 
a despeito de ser algo considerado divino. Não se conhece nenhuma língua descida do céu. ${ }^{6}$

O texto bíblico funciona como essa mensagem humana divinizada, cadenciada, romantizada pela alma humana que busca no transcendente possíveis respostas para suas perguntas mais profundas. Nesse percurso, a razão humana encontra hoje o caminho da também necessária crítica entre o discurso teológico e o fazer literário, como uma balança. Um lado equilibra o outro, buscando no meio termo entre os extremos, um caminho virtuoso e frutuoso:

O modelo da correlação/contraste entre o fazer teológico e o fazer literário foca, em geral, as conexões possíveis entre o literário e o teológico. Parte do pressuposto de que há uma imprecisão de limites entre o discurso literário, objeto da fruição estética e da crítica literária, e o discurso religioso, objeto da fruição religiosa e da teologia. O texto literário não se oferece como objeto de leitura apenas à crítica literária, assim como o texto de caráter religioso não se reduz a mero objeto de estudo da teologia. Assim, por exemplo, antes de ser interpretado como palavra de Deus, o texto bíblico se entende como mito, saga, lenda, canto. E, nesse sentido, pode interessar ao leitor de literatura. Da mesma forma, a literatura, ao redescrever o mundo com seu poder heurístico, se oferece como fértil terreno para a teologia. ${ }^{7}$

Uma Teologia equilibrada necessita da crítica histórica, sociológica e literária dos textos na qual baseia sua reflexão: os textos bíblicos. $\mathrm{Da}$ mesma forma a crítica literária quando toma um objeto religioso, teológico ou espiritual diante de si necessita reencontrar o sagrado perdido no meio das palavras humanas, como nos lembra Giorgio Agamben: "Só podemos ter acesso ao mistério por meio de uma história e, todavia (ou, talvez, caberia dizer de fato), a história é aquilo em que o mistério apagou ou escondeu seus fogos."

$6 \quad$ BRANDÃO, Eli. Revista Estudos de Religião. São Bernardo do Campo: UNESP. Ano XIX, n. 29, dez. 2005, p. 166.

7 CANTARELLA, Antônio Geraldo. A pesquisa em Teopoética no Brasil: pesquisadores e produção bibliográfica. Horizonte. Belo Horizonte, v. 12, n. 36, out./dez. 2014, p. 1246.

8 AGAMBEN, Giorgio. O fogo e o relato: ensaios sobre a criação, escrita, arte e livros. São Paulo: Boitempo, 2018. p. 31. 
No decorrer da história da humanidade houve uma queda, um distanciamento entre a linguagem humana e a linguagem divina, como afirma Carvalho:

Para os românticos, havia uma linguagem original compartilhada por Deus e os homens. Essa linguagem permitia ao homem uma comunhão total com o universo, sem mediação. Houve, todavia, uma "queda", um distanciamento entre a linguagem divina e a linguagem humana, estabelecendo-se assim um caos. Já não pode mais a linguagem humana expressar o divino, falar do inefável. A poesia surge então como possibilidade de reconstrução, recriação, restauração do contato perdido. ${ }^{9}$

Hoje quem pode nos ajudar nessa busca pela linguagem perdida? Os poetas, que nos ensinam a criar e rezar com mais fecundidade, a enxergar outras coisas, a ler com outra linguagem, a experimentar essências novas, a descobrir sentidos ocultos, a contemplar uma beleza escondida, a encontrar Deus nas entrelinhas dos textos, pois: "Deus é personagem literário, que, como qualquer outro personagem, cresce ou diminui à medida que dialoga com outros personagens." 10

A poesia tem uma sensibilidade extremamente apurada, capaz de captar, fotografar e transliterar no verso a realidade pelo seu avesso, pelo seu mistério, a sua alma, a sua essência. Relembramos eles:

"Dois olhos não são bastantes para captar o que se oculta no rápido florir de um gesto". "11

"Sob o sol quente, no jardim flamejante/ a varejeira rebrilha, joia viva./ O poder de Deus me aterra em sua inércia./ Não vai impedir a mosca de botar seus ovos/sobre a língua defunta que lhe cantou as obras./ Tremo, obrigado que sou/ a ver Seu rosto sob os vermes. "12

9 CARVALHO, Vinícius Mariano de. Religião e Literatura: algumas inter-relações possíveis. Numem: Revista de estudos e pesquisa da religião. Juiz de Fora: UFJF, v. 4, n. 1, jan./jun. 2001, p. 42-43.

10 MAGALHÃES, A. C. De Melo et al. Deuses em poéticas: estudos de literatura e teologia. João Pessoa: EDUEPB, 2008. p. 15.

11 ANDRADE, Carlos Drummond de. Amar se aprende amando: poesia de convívio e de humor/ Carlos Drummond de Andrade; posfácio Fabio Cesar Alves. São Paulo: Companhia das Letras, 2018. p. 52.

12 PRADO, Adélia. A duração do dia/Adélia Prado. 2. ed. Rio de Janeiro: Record, 2011. p. 62. 
"Cordeiro de deus que lava os pecados do mundo/ me diga quantas maçãs há no paraíso terreno". ${ }^{13}$

"Tudo deu certo, meu velho Heráclito,/ porque eu sempre consigo/ atravessar esse teu rio/ com o meu eternamente outro. "14

"Não despertes o que não podes calar". "Mas levamos anos/ a esquecer alguém/ que apenas nos olhou." 15

"Como dois e dois são quatro/ sei que a vida vale a pena/ embora o pão seja caro/ e a liberdade pequena". "Sou como você/feito de coisas lembradas/ e esquecidas". 16

“E acho que só para ouvir o vento passar vale a pena ter nascido”. ${ }^{17}$

"Me desespero porque não posso estar presente a todos os atos da vida... A morte revelará o sentido verdadeiro das coisas... Sou a presa do homem que fui a vinte anos passados ". ${ }^{18}$

Através desses poetas do passado e do presente podemos nos ocupar com a busca pela linguagem perdida, e também pelo encontro de uma espiritualidade poética, que transcende os limites do mundo palpável. As religiões tocam naquilo que o ser humano deseja transcender e através de símbolos, imagens, sons, gestos realizam uma ponte entre a realidade imanente e aquilo que está além. Tocar nas coisas reais, concretas, diárias é o que a poesia faz em contato com a religião, como afirma Paulo Nogueira:

A religião, para ser relevante - esse é um conceito fundamental nesse debate -, tem que falar sobre as coisas reais, tem que ser um apelo às coisas concretas. [...] Em nosso estudo partimos da observação de que as tradições religiosas - e não apenas o cristianismo - têm uma resistência ao tratamento convencional da realidade, em especial em suas narrativas míticas e em suas tradições populares orais. As religiões,

13 PARRA, Nicanor. Só para maiores de cem anos: antologia anti(poética)/Nicanor Parra; seleção e tradução de Joana Barossi e Cide Piquet; edição bilíngue. São Paulo: Editora 34, 2018. p. 118.

14 QUINTANA, 2005, p. 513.

15 MENDONÇA, José Tolentino. A noite abre meus olhos: poesia reunida. Lisboa: Assírio \& Alvim, 2006. p. 41.

16 GULLAR, Ferreira. Dentro da noite veloz/Ferreira Gullar; prefácio Armando Freitas Filho. São Paulo: Companhia das Letras, 2018. p. 34, 40.

17 PESSOA, Fernando. Poesia completa de Alberto Caeiro/Fernando Pessoa; edição Fernando Cabral Martins, Richard Zenith. São Paulo: Companhia das Letras, 2005. p. 91.

18 MARICONI, Italo (org.). Os cem melhores poemas brasileiros do século. Rio de Janeiro: Objetiva, 2001. p. 68. 
para falar sobre o mundo e a realidade - e de fato pressupomos que o fazem! - , discursam sobre mundos, personagens e ações imaginários e fantásticos. ${ }^{19}$

Quando usamos a linguagem do cotidiano temos a sensação de que falamos sobre o real, e que a linguagem e o real estão fundidos. Quando nos deparamos com a linguagem da arte poética e das tradições religiosas, temos surpresas, especialmente nas narrativas e metáforas, pois "elas nos mostram, por meio de deformações das convenções, que toda a nossa linguagem sobre o mundo repousa sobre convenções e nos propõe outras, as fantásticas, para pensarmos o mundo." ${ }^{20}$

Pensar e sentir o mundo além das convenções socialmente estabelecidas nos propõe a poesia e a espiritualidade. Na vontade de pensar e sentir o mundo, o ser humano sedento em encontrar um sentido na vida através da espiritualidade e da poesia produz uma vontade de sentido, como propôs a Logoterapia de Viktor Frankl. Segundo Alex Villas Boas, o ser humano "sofre a esperança que se lhe provoca perante o sentido que se desvela como possibilidade nova de ser, ou sofre a angústia do que lhe provoca a sensação de uma vida sem sentido, ou ainda quando o sentido da vida se esvai diante do fatídico." ${ }^{21}$ Ou seja, diante do esperançar-se e do angustiar-se o ser humano projeta em linguagem para o mundo real, o que o perturba, incomoda, alegra e anima interiormente como ser no mundo, ser poético e ser espiritual.

\section{Espiritualidade e poesia}

Poesia e oração requerem tempo, por que "A pressa é a ruína dos santos e dos artistas"22. Drummond de Andrade diz: "convive com teus poemas antes de escrevê-los/ tem paciência se obscuros, calma se te provocam"23. As vezes lemos um livro de poemas deste ou daquele

19 NOGUEIRA, Paulo Augusto de Souza (org.). Religião e Linguagem: abordagens teóricas interdisciplinares. São Paulo: Paulus, 2015. p. 116.

20 NOGUEIRA, 2015, p. 118-119.

21 BOAS, Alex Villas. Teologia em diálogo com a Literatura: origem e tarefa poética da teologia. São Paulo: Paulus, 2016. p. 130.

22 MERTON, Thomas. Novas sementes de contemplação. Tradução de Ir. Maria Emmanuel de Souza e Silva; revisão da tradução, Sieni Maria Campos. Petrópolis: Vozes, 2017. p. 98.

23 ANDRADE, Carlos Drummond de. Antologia poética/Carlos Drummond de Andrade; organizada pelo autor. São Paulo: Companhia das Letras, 2012. p. 219. 
autor e não encontramos nenhum que seja nosso, escrito para o nosso eu. Não que a poesia dele ou dela seja ruim, apenas não foi escrita para nossa alma. Mas quando nos deparamos com versos que nos tocam, eles como que ficam gravados em nosso ser, passam a fazer parte do nosso eu, tornam-se oxigênio literário e vão nos acompanhando por onde quer que vamos. Viram uma espécie de segunda pele.

No tocante a oração não é diferente: há dias que não sentimos, não escutamos, não descobrimos nada. E há os dias de encontros. Experiências místicas que preenchem o vazio deixado pelos dias anteriores - vazio absolutamente necessário, diga-se de passagem. Só há uma forma de rezar: dispondo de tempo para tal. Só há um jeito de tornar a alma poética: lendo os poetas e descobrindo quais os que tem alma semelhante à nossa alma, quais os que dialogam conosco, quais são parte da nossa família, têm o mesmo sangue que o nosso correndo nas veias. Tudo isso sem perder a originalidade, a ipseidade, a idiossincrasia, a singularidade. Em poesia e espiritualidade não há a cópia da cópia de Platão.

Muitos poetas não são poetas pela mesma razão porque muitos homens religiosos não são santos: jamais conseguem ser eles mesmos. Nunca chegam a ser o poeta ou o monge que Deus os destinou a ser. Nunca se tornam o homem ou o artista que estavam chamados a ser pelas circunstâncias especiais de suas vidas individuais. Desperdiçam a vida em vãos esforços para se tornarem algum outro poeta, algum outro santo. Por diversos motivos absurdos, estão convencidos de que são obrigados a se tornarem iguais a alguém que morreu duzentos anos atrás e viveu em circunstâncias profundamente alheias às suas. ${ }^{24}$

Cada qual precisa tecer, dia após dia, sua filigrana espiritual e poética, de modo único e irrepetível, uma impressão digital da alma. Acontece com a poesia o mesmo que acontece com a Palavra de Deus. De repente, um versículo invade nosso ouvido, revoluciona nosso interior, nos questiona ou nos dá uma luz, preenche um espaço que pertence somente àquela palavra, leva-nos à transcendência naquele exato instante ou nos acompanha para o resto da vida. O texto sagrado, com toda a força que contém, cria um mundo novo. Dizemos: é só uma palavra, é apenas um verso! Não! É poesia, é criação, é um sopro de vida, é inspiração divina.

$\mathrm{Na}$ poesia acontece essa mesma liturgia. Escrever um poema é um ato criador, é um dar à luz algo que nasceu dentro de si e agora

24 MERTON, 2017, p. 110. 
quer encontrar o papel em branco. "É preciso escrever um poema várias vezes para que dê a impressão de que foi escrito pela primeira vez" 25 , revela Quintana com toda propriedade. Já Ferreira Gullar diz que a poesia nasce do espanto. Tal como de repente um versículo nos revoluciona, a poesia, de repente, revela uma verdade que não poderia ser dita ou intuída senão por esta verve. "O poeta entra em si mesmo para criar. O contemplativo mergulha em Deus para ser criado" 26 . Dois olhares de um mesmo rosto. Olhares que se encontram. Poesia e espiritualidade experimentam esse encontro, eu diria, inevitável, ainda que imprevisto. Dizemos imprevisto pelo simples fato de que há um espírito presente em ambas, envolto em certa dose de mistério, que faz as duas desembarcarem, certo momento, na mesma estação, no mesmo porto, no mesmo ataúde. Se fruto do acaso ou da lei natural, também não sabemos.

Quando um poeta escreve, ele está rezando, mesmo que seus versos sejam blasfemos, heréticos, profanos, porque "um belo poema - ainda que de Deus se aparte - um belo poema sempre leva a Deus" 27 . Fernando Pessoa em seu $O$ guardador de rebanhos prova-nos isso. Sua poesia cria um menino Jesus que não sabemos se é apenas humano ou nada divino, ou uma mistura de ambos, se é fiel a algum evangelho, se é um exemplo a ser seguido, se terá condições de nos salvar quando se tornar adulto. Contudo, é uma criança e isto basta para que seja místico. Em $O$ guardador de rebanhos, o Jesus de Pessoa é um menino que:

"Tinha fugido de céu./ Era nosso demais para fingir/ de segunda pessoa da trindade./ No céu era tudo falso, tudo em desacordo/ Com flores e árvores e pedras./No céu tinha que estar sempre sério/ E de vez em quando de se tornar outra vez homem/ E subir para a cruz, e estar sempre a morrer/Com uma coroa toda à roda de espinhos/E os pés espetados por um prego com cabeça,/ E até com um trapo à roda da cintura/Como os pretos nas ilustrações. [...] Um dia que Deus estava a dormir/E o Espírito Santo andava a voar,/ Ele foi à caixa dos milagres e roubou três./ Com o primeiro fez com que ninguém soubesse que ele tinha fugido./ Com o segundo criou-se eternamente humano e menino./ Com o terceiro criou um Cristo eternamente na cruz/ E deixou-o pregado na cruz que há no

\footnotetext{
25 QUINTANA, 2005, p. 331.

26

MERTON, 2017, p. 110.

27 QUINTANA, Mario. Antologia poética/Mario Quintana. Rio de Janeiro: Objetiva, 2015. p. 121.
} 
céu/ E serve de modelo às outras./ Depois fugiu pelo sol/ E desceu no primeiro raio que apanhou./ Hoje vive na minha aldeia comigo [...]". ${ }^{28}$

Para aquele que está convicto de sua fé, professa-a com serenidade e cultiva uma sensibilidade poética, o texto não fere, não agride, não ofende, ao contrário, dá leveza à humanidade de uma criança que sabe ser mais do que uma simples criança. É aqui que a poesia brinca, baila, passeia pela terceira margem do rio de Guimarães Rosa. É aqui que o poeta se torna um rezador. A poesia, enxugando um pouco da doxa da religião institucionalizada, dá leveza ao espírito humano sedento de palavras leves, pois ela própria (a religião) "precisaria ser menos doxa e teria que recuperar o elemento paradoxal constitutivo da religião"29, afirma Antônio Magalhães no livro organizado por Nogueira.

Ao mesmo tempo, quando rezamos é bom que sejamos poéticos em nossa espiritualidade. Não dá para rezar apenas com o catecismo, com o dogma, com os conceitos teológicos, apenas com as fórmulas fixas e definidas, tão somente com a estética das gestualidades e ritos, porém vazios de poesia. Não se trata de adornar a oração com confetes. Isso serve para qualquer forma de espiritualidade. Poesia não é enfeite, não é mero detalhe, não é perfumaria. A ars poética da espiritualidade é chegar à essência continuando pelo mesmo caminho. Se a poesia é orante, a espiritualidade é poética. Quem conseguiria enxergar beleza na morte senão a poesia? Jesus diz "Não chores" (Lc 7,13) para a viúva de Naim em pleno cortejo fúnebre; por outro lado, chora a morte de Lázaro, arrancando comentários: "Vejam como ele o amava" (Jo 11,36). Há poesia no consolo, há poesia na lágrima. A poesia, sem disfarçar a verdade ou camuflar a realidade, sem se perder em ilusões oníricas, sem tergiversar o conteúdo do discurso ou divagar por falta de propósitos, ela também professa uma fé - de beleza transcendental. É dessa beleza que a religião se ocupa, e fala, e abraça em seus símbolos, gestos e espiritualidades, pois como também afirma Magalhães:

A religião é um leque amplo e complexo de experiências, tradições, discursos, falas, normatizações, rupturas, revoluções, tiranias, profecias,

28 PESSOA, Fernando. Poesia completa de Alberto Caeiro/Fernando Pessoa; edição Fernando Cabral Martins, Richard Zenith. São Paulo: Companhia das Letras, 2005. p. 28-29.

29 NOGUEIRA, 215, p. 179. 
poesias, repressões, sexo, erotismo. A religião é paradoxal, com profusão de deslocamentos e paradoxos na construção dos sentidos. ${ }^{30}$

Tão paradoxal é também a arte poética: a poesia reconcilia as coisas, algo próprio da espiritualidade. A poesia toca o mistério da vida, pelo que a espiritualidade também anseia. A poesia eleva o ser, não diferente daquilo que a espiritualidade faz. A poesia trabalha com as essências, igualmente a espiritualidade sadia. A poesia quanto mais simples mais profunda, por sua vez, a espiritualidade se torna tão mais nobre quanto mais simples. Não o excesso de palavras, não um dicionário aguçado, não os florilégios desconexos, não prolixidades e devaneios, não excentricidades desencarnadas. Tanto espiritualidade quanto poesia se unem nos seus paradoxos: dizem e calam, criam mundos e vazios, velam, desvelam e revelam. São primárias e necessárias à vida.

\section{O Baú da Memória}

O ser humano é um ser de memória. O seu estado presente e a construção do futuro são possíveis pois ele olha para o passado, resgata na memória seus feitos, conquistas, aprendizados, derrotas, vitórias. A memória é um ambiente poético e espiritual por excelência, uma espécie de ventre em estado permanente de gravidez. Quando Cristo diz "Fazei isto em memória de mim" (Lc 22,19), há nessa ordem e no anúncio que daí deriva - Eis o mistério da fé! - uma poesia deveras, pois aquelas palavras do memorial criam Deus naquele pão e naquele vinho, dando à luz a si mesmo. Não se trata apenas de uma lembrança, de uma saudade, de uma sensação semelhante ao que acontecera outrora, mas uma realidade que se torna presente, que faz viver - a poesia é a arte de criar.

Acaso não é assim na oração? Quando rezamos temos a certeza de que não estamos sozinhos, há uma presença misteriosa com a qual nos relacionamos, há certeza de haver um Outro. E com o que rezamos senão com a memória da vida! "Recorda os dias que se foram, repassa gerações e gerações... Pergunte ao teu pai e ele te contará, interroga os anciãos e eles te dirão" (Dt 32,7). A poesia, de certo modo, realiza esta façanha de eternidade, ela guarda as lições que perduram apesar do tempo. Guardar e eternizar: atividades próprias da memória.

30 NOGUEIRA, 2015, p. 179. 
Dificil fotografar o silêncio. Entretanto tentei. Eu conto: [...] Ia o silêncio pela rua carregando um bêbado. Fotografei esse carregador. [...] Vi ainda um azul-perdão no olho de um mendigo. Fotografei o perdão. Olhei uma paisagem velha a desabar sobre uma casa. Fotografei o sobre. Foi dificil fotografar o sobre. ${ }^{31}$

Os versos cultivam vivos os fragmentos de um instante, a inspiração de um ato, nos seus silêncios as canções, e cada vez que voltamos a eles aquele instante revive, aquele ato recria-se, aquela música ressoa, $o$ tempo evapora-se e fica a eternidade - de modo novo e único para cada leitor, para cada poeta. Como diz Primo Vieira, em Céus longínquos, sempre dentro da luz diáfana do mistério. "Na mesma paisagem/ os mesmos pássaros cantam/ e a infância não volta..."32

E o que inspira o poeta e o orante? Não pode ser outra coisa senão a vida. Um poema ou uma prece que não sejam um pulsar do coração, um respirar profundo, um grito de revolta ou um frêmito de gratidão, ambos vertendo de dentro, uma pergunta ou uma resposta ante as circunstâncias, não é poesia nem prece. A matéria prima da espiritualidade, da mística, da oração, dos versos, o seu barro informe e impuro, é o sangue. Onde há sangue, há vida. Não obstante, espiritualidade e poesia são janelas para o infinito, para a contemplação, para o mistério do tudo e do nada.

Como citamos, a humanidade, ao longo de sua história, afasta-se cada vez mais das fontes do mistério e perde, pouco a pouco a lembrança daquilo que a tradição lhe ensinara a história. Segundo Giorgio Agamben, só podemos ter acesso ao mistério por meio de uma história, a história por sua vez, é aquilo em que o mistério apagou ou tentou apagar da memória. ${ }^{33}$ Uma anedota escrita por Scholem, num livro sobre a mística judaica nos ajuda a compreender:

Quando Baal Chem, fundador do hassidimo ${ }^{34}$, tinha uma tarefa dificil pela frente, ia a certo lugar no bosque, acendia um fogo, fazia uma prece, e o que ele queria se realizava. Quando, uma geração depois, o Maguid

31 BARROS, Manoel de. Poesia completa/ Manoel de Barros. São Paulo: Leya, 2010. p. 379-380.

32 GUTTILLA, Rodolfo Witzig (org.). Haikais tropicais. São Paulo: Boa Companhia, 2018. p. 131.

33 Cf. AGAMBEN, 2018, p. 27.

34 O hassidismo é um movimento surgido no interior do judaísmo ortodoxo que promove a espiritualidade, através da popularização e internalização do misticismo judaico, como um aspecto fundamental da fé judaica. 
de Mesritsch viu-se diante do mesmo problema, foi ao mesmo lugar do bosque e disse: "Já não sabemos acender o fogo, mas podemos proferir as preces", e tudo aconteceu segundo seus desejos. Passada mais uma geração, o Rabi Moshe Leib de Sassov viu-se na mesma situação, foi ao bosque e disse: "Já não sabemos acender o fogo, nem sabemos as preces, mas conhecemos o local no bosque, e isso deve ser suficiente", e, de fato, foi suficiente. Mas, passada outra geração, o Rabi Israel de Rijn, precisando enfrentar a mesma dificuldade, ficou em seu palácio, sentado em sua poltrona dourada, e disse: "Já não sabemos acender o fogo, não somos capazes de declamar as preces, nem conhecemos o local do bosque, mas podemos narrar a história de tudo isso". E, mais uma vez, isso foi suficiente. ${ }^{35}$

Essa anedota é uma alegoria da literatura. A humanidade afasta-se cada vez mais das fontes do mistério e perde aos poucos a memória daquilo que a tradição ensinou sobre alguns elementos indispensáveis para resolver as dificuldades do mundo. Mesmo assim a humanidade ainda tem memória para lembrar e contar tudo isso. O que resta do mistério que foi perdido, esquecido e abandonado? A literatura. A literatura é o que resta do mistério. E é assim, a quase vã tentativa de explicação do inefável. Por isso, "Antes de me despedir/ Tenho direito a um último desejo:/ Generoso leitor/ queime este [texto]/ Não representa o que eu quis dizer/Apesar de ter sido escrito com sangue/ não representa o que eu quis dizer" ${ }^{\prime 36}$. Mas foi tudo o que conseguimos. Por fim, fica o Lembrete: "Se procurar bem, você acaba encontrando/ não a explicação (duvidosa) da vida/ mas a poesia (inexplicável) da vida". ${ }^{37}$

\section{Conclusão}

O título de nosso artigo contém as colunatas que sustentam as intuições aqui expressadas. Dois universos imensos, o da Teologia e o da Literatura, cada qual com suas particularidades e excentricidades, dialogando em perfeita harmonia, como o lobo e o cordeiro do Apocalipse. Dentro desses universos dois mundos, o da Poesia e o da Mística, que se fecundam reciprocamente e tecem uma única trama, costurada com os cetins e os trapos da vida, tornando-a colorida e vária, viajando

\footnotetext{
35 AGAMBEN, 2018, p. 27-28.

36 PARRA, 2018, p. 151.

37 ANDRADE, Carlos Drummond de. Poesia completa: conforme as disposições do autor. São Paulo: Nova Aguilar, 2012. p. 1256.
} 
da realidade à transcendência sem prejuízo de ambas, gentilmente acomodadas no colo da Memória.

Acenamos como Literatura e Teologia se relacionam em um tripé: poesia, espiritualidade e memória. Primeiramente vimos que a Teopoética busca desde o primeiro passo dado pelos românticos na arte, uma crítica estético-literária à religião, e também uma crítica religiosa à estética, à arte. Mas só no século XX a Teologia e a Literatura começam a aprofundar sua relação em alguns círculos acadêmicos. Com isso podemos mostrar como a poesia e espiritualidade se relacionam: acontece com a poesia o mesmo que acontece com a Palavra de Deus. Um ou outro versículo invade nosso ouvido, revoluciona nosso interior, nos questiona ou nos dá uma luz. Ao mesmo tempo, unindo poesia e espiritualidade mostramos também a importância da memória: esta é um ambiente poético e espiritual. Quando Cristo diz "Fazei isto em memória de mim" (Lc 22,19), há nessa ordem e no anúncio que daí deriva - Eis o mistério da fé! - uma poesia verdadeira, pois aquelas palavras do memorial trazem Deus ao pão e ao vinho.

O que expomos aqui, trata-se apenas de um aperitivo, cuja intenção é atiçar o paladar do leitor para uma busca pessoal que lhe alimente o espírito. Sem fugir da canonicidade técnica, da modalidade cartesiana necessária, dos enquadramentos normativos para sua construção, tentamos ser profundos como exige a Teologia, espontâneos como é próprio da Literatura, leves e místicos, pois, assim se mostram a Poesia e a Espiritualidade. Não se pode perder nada disso, o que comprova a indispensável atuação da Memória, da qual este artigo se faz guardador.

\section{Referências}

AGAMBEN, Giorgio. O fogo e o relato: ensaios sobre a criação, escrita, arte e livros. São Paulo: Boitempo, 2018.

ANDRADE, Carlos Drummond de. Amar se aprende amando: poesia de convívio e de humor/Carlos Drummond de Andrade; posfácio Fabio Cesar Alves. São Paulo: Companhia das Letras, 2018.

ANDRADE, Carlos Drummond de. Antologia poética/Carlos Drummond de Andrade; organizada pelo autor. São Paulo: Companhia das Letras, 2012. 
ANDRADE, Carlos Drummond de. Poesia completa: conforme as disposições do autor. São Paulo: Nova Aguilar, 2012.

BARROS, Manoel de. Poesia completa/Manoel de Barros. São Paulo: Leya, 2010.

BÍBLIA de Jerusalém. 7. ed. São Paulo: Paulus, 2011.

BINGEMER, Maria Clara. Teologia e Literatura: afinidade e segredos compartilhados. Petrópolis: Vozes, 2015.

BOAS, Alex Villas. Teologia em diálogo com a Literatura: origem e tarefa poética da teologia. São Paulo: Paulus, 2016.

BRANDÃO, Eli. Revista Estudos de Religião. São Bernardo do Campo: UNESP. Ano XIX, n. 29, dez. 2005.

CANTARELLA, Antônio Geraldo. A pesquisa em Teopoética no Brasil: pesquisadores e produção bibliográfica. Horizonte. Belo Horizonte, v. 12, n. 36, out./dez. 2014.

CARVALHO, Vinícius Mariano de. Religião e Literatura: algumas inter-relações possíveis. Numem: Revista de estudos e pesquisa da religião. Juiz de Fora: Editora UFJF. v. 4, n. 1, jan./jun. 2001.

GULLAR, Ferreira. Dentro da noite veloz/Ferreira Gullar; prefácio Armando Freitas Filho. São Paulo: Companhia das Letras, 2018.

GUTTILLA, Rodolfo Witzig (org.). Haikais tropicais. São Paulo: Boa Companhia, 2018.

KUSCHEL, Karl Joseph. Os escritores e as escrituras: retratos teológicos-literários. São Paulo: Loyola, 1999.

MAGAlHÃeS, A. C. De Melo et al. Deuses em poéticas: estudos de literatura e teologia. João Pessoa: EDUEPB, 2008.

MARICONI, Italo (org.). Os cem melhores poemas brasileiros do século. Rio de Janeiro: Objetiva, 2001.

MENDONÇA, José Tolentino. A noite abre meus olhos: poesia reunida. Lisboa: Assírio \& Alvim, 2006.

MERTON, Thomas. Novas sementes de contemplação. Tradução de Ir. Maria Emmanuel de Souza e Silva; revisão da tradução, Sieni Maria Campos. Petrópolis: Vozes, 2017. 
NOGUEIRA, Paulo Augusto de Souza (org.). Religião e Linguagem: abordagens teóricas interdisciplinares. São Paulo: Paulus, 2015.

PARRA, Nicanor. Só para maiores de cem anos: antologia anti(poética)/ Nicanor Parra; seleção e tradução de Joana Barossi e Cide Piquet; edição bilíngue. São Paulo: Editora 34, 2018.

PESSOA, Fernando. Poesia completa de Alberto Caeiro/ Fernando Pessoa; edição Fernando Cabral Martins, Richard Zenith. São Paulo: Companhia das Letras, 2005.

PRADO, Adélia. A duração do dia/Adélia Prado. 2. ed. Rio de Janeiro: Record, 2011.

QUINTANA, Mario. Mario Quintana: poesia completa: em um volume. Org. Tania Franco Carvalhal. Rio de Janeiro: Nova Aguilar, 2005.

QUINTANA, Mario. Antologia poética/Mario Quintana. Rio de Janeiro: Objetiva, 2015. 